\title{
Pituitary Gland Mixed Acidophil-Basophil
}

\section{Carcinoma}

National Cancer Institute

\section{Source}

National Cancer Institute. Pituitary Gland Mixed Acidophil-Basophil Carcinoma. NCI

Thesaurus. Code C4149.

A malig nant epithelial neoplasm of the anterior pituitary gland in which the neoplastic cells stain positive with acidic and basic dyes. 